\title{
Alman Medyasının Eleștirel Söylem Analizi: 24 Haziran 2018 Türkiye Genel Seçimleri
}

\author{
A Critical Discourse Analysis of German Media: 24 June 2018 General Elections of Turkey
}

\section{Soner TAUSCHER ${ }^{*}$ Osman ERDOĞDU ${ }^{* *}$ Şebnem KORKMAZ ${ }^{* *}$}

Öz

2010 sonrasında gerçekleşen Arap Baharı, Suriye İç Savaşı, Mülteci Krizi ve DAEŞ’in yükselişi gibi olaylar Ortadoğu devletlerinin yönetimlerini istikrarsızlaştırırken bir güç boşluğu da ortaya çıkarmıştır. Bölgede, siyasi olarak daha istikrarlı ve ekonomik olarak görece güçlü bir konumda bulunan Türkiye, bölge dışı ülkeler açısından da önemli bir uluslararası muhatap haline gelmiştir. Türkiye’nin farklılaşan dış politikasıyla birlikte bölgede, $\mathrm{ABD}$ ve güçlü $\mathrm{AB}$ ülkeleriyle her zaman uyumlu hareket etmemesi dış basının dikkatini Türkiye’nin ve özellikle mevcut hükümetin üzerine daha fazla çekmiştir. Genel olarak Avrupa, özelde ise Alman basınında Türkiye’de yaşanan iç ve dış siyasi gelişmeler ayrıntılı, ancak genellikle olumsuz olarak ele alınmaktadır. Türkiye’de yaşanan gelişmelere dair Avrupa basınında hemen her gün birçok haber, röportaj ve belgesel yayınlanmaktadır. Ancak bu haberlerin oluşturduğu söylem üzerine oldukça az sayıda araştırma bulunmaktadır. Bu makalenin amacı, bu boşluğa işaret ederek Alman medyasının iki önemli yayın organı olan Tageszeitung ve Süddeutsche Zeitung gazetelerinin 24 Haziran 2018 Türkiye Genel Seçimleri üzerinden Türkiye, Türkiye’deki önde gelen siyasi figürler ve meseleler üzerine nasıl bir söylem geliştirdiğini eleştirel söylem analizi bağlamında ele almaktır.

Anahtar Kelimeler: Türkiye, 24 Haziran Türkiye Genel Seçimleri, Tageszeitung, Süddeutsche Zeitung, Eleştirel Söylem Analizi

\footnotetext{
Arş. Gör., Sakarya Üniversitesi, Diaspora Araştırmaları Merkezi, Sakarya, Türkiye, sonert@sakarya.edu.tr. Orcid ID: 0000-0001-7310-5661

** Dr. Öğrencisi, Sakarya Üniversitesi, Diaspora Araştırmaları Merkezi, Sakarya, Türkiye, osman.erdogdu@ogr.sakarya. edu.tr. Orcid ID: 0000-0003-3601-3703

*** Yüksek Lisans Öğrencisi, Sakarya Üniversitesi, Diaspora Araştırmaları Merkezi, Sakarya, Türkiye, sebnem-korkmaz@ outlook.com. Orcid ID: 0000-0003-4830-3118
} 


\begin{abstract}
Events like Arab Spring, Syrian Civil War, Refugee Crisis and the rise of DAESH that happened after 2010, lead to destabilization of political situation and governments in many of the Middle Eastern countries and created a power vacuum in the region. Turkey with its politically stable and relatively strong economic power became one of the countries to be first contacted in the region. Turkey's changing foreign policy also started to drift apart from the US and EU's regional foreign policy which brought the attention of the foreign media on Turkey and especially on the government. European in general and German media in particular started cover the domestic policy and foreign policy of Turkey in detail and generally depicts it negatively. Events in Turkey are covered with news, interviews and documentaries in the European media on nearly daily basis. However, there are very few research on the discourse used in those news. This article aims to point this gap through subjecting the discourse created on 24 June 2018 Turkish Early General Elections by two important German media organ, Tageszeitung and Süddeutsche Zeitung, to the critical discourse analysis.
\end{abstract}

Keywords: Turkey, 24 June Turkish Early Elections, Tageszeitung, Süddeutsche Zeitung, Critical Discourse Analysis

\title{
Giriș
}

Almanya ile Türkiye arasındaki diplomatik ilişkilerin tarihi yüzlerce yıl öncesine dayanmasına rağmen, kültürlerarası etkileşim 1960’larda başlayan işçi göçüyle ortaya çıkmıştır. 1970’li yıllarda küresel çapta yaşanan ve Avrupa ülkelerini de etkileyen ekonomik kriz ve misafir işçilerin kalıcı olmaya başlayıp sosyal hayatta görünür hale gelmesi Alman toplumunun bir kısmı için sorun oluşturmaya başlamıştır. Alman sağının gözünde 1930'lar ve 1940'ların ötekisi Yahudilerin ve 1950'ler ile 1960'ların ötekisi komünistlerin yerini, 1980'ler ve 1990'larda Türkler almıştır. 2001 yılında yaşanan 11 Eylül olayları ise Avrupada ötekinin yönünü Türklerden genel olarak Müslümanlara çevirmiştir. Suriye İç Savaşıłyla başlayan süreçte ortaya çıkan DAEŞ terör örgütünün Avrupa ülkelerinde varlığını hissettirmesi ve Suriyeli göçmenlerin 2014 yılından itibaren Türkiye üzerinden artarak Avrupa Birliği’ne $(\mathrm{AB})$ sığınma talebiyle akın etmeleri Avrupa toplumunda mevcut öteki karşıtlı̆̆ını körüklemiş, 2008'deki finansal krizin de etkisiyle artan işsizlik ve güvensizlik ortamında artık hem siyasi hem de akademik olarak İslamofobiden bahsedilmeye başlanmıştır. ${ }^{1}$ Yaşanan finansal krizi aşmak için devletlerin ulusal çıkarlarını ön plana alması, Avrupa toplumlarındaki aşırı sağın ve yabancı karşıtı söylemlerin güçlenmesine yol açmıştır (Bezci, 2017, s. 10-13). Avrupa'ya giden Suriyeli, Iraklı ve Afgan sığınmacıların AB'den önceki son sınır kapısı olması, Türkiye’nin AB üzerindeki yumuşak gücünün de artmasına neden olmuştur. Fakat Avrupalı muhafazakârlar ile aşırı sağcıların Türkiye ve Cumhurbaşkanı Recep Tayyip Erdoğan’a yönelik tepkilerinin tek sebebi kendi kültür ve dinleri için tehlikeli buldukları Müslüman mültecilerin Avrupa'ya akın edip etmemelerinin anahtarının Erdoğan’ın elinde bulunduğuna inanmaları değildir. Türkiye’nin 2005 yılında AB ile tam üyelik müzakerelerine başlaması da birçok $\mathrm{AB}$ üyesi ülkenin muhafazakâr ve aşırı sağ kesiminde tepkiyle karşılanmıştır. Bilindiği üzere İngiltere’de yaşanan Brexit sürecinin ana temalarından biri, Türkiye’nin olası AB üyeliği olmuştur. Bunun yanında, Suriye İç Savaşı’nın ve ABD’nin Irak’tan

12015 yılını 2016 yılana bağlayan yılbaşı gecesi yaşanan taciz ve gasp olayları genelde Avrupa ülkelerinin özelde ise Alman toplumunun mültecilere olan bakışının sorgulanmasına yol açmıştır (Yardım, 2017, s. 221). 
çekilmesinin bölgede ortaya çıkardığı otorite boşluğu, zaman içerisinde Türkiye’nin hem iç hem de dış politikada Batı dünyasıyla uyumlu politikalar izlemesine engel olmuştur. Türkiye’nin bu "uyumsuz" politikası Batılı müttefikleri tarafından bir tür başına buyrukluk olarak nitelendirilmiştir.

Tüm bunların yanında, Arap Baharı’nın etkisiyle çoğunluğu Müslüman ülkelerde oluşan iktidar boşlukları ve yaşanan istikrarsızların bitiş/başlangıç sınırında bulunması, Türkiye'yi Alman siyasileri ve medyası için muhatap alınacak birincil ülkelerden biri konumuna getirmiştir. Batı dünyası açısından uyumsuz görülen Türkiye Cumhuriyeti ve Cumhurbaşkanı Erdoğan, siyasi ve medyatik söylemlerle tekrar uyumlu hale getirilmeye çalışılmaktadır.

Bernard Cohen'in 1963 yllında belirttiği üzere medya, insanların nasıl düşünmesi gerektiği üzerinde etkili olamamakla birlikte, gündeme taşıdığı haberlerin seçimi, türdeş haberlerin benzer yorumlarına defalarca yer verilmesi üzerinden kamuoyunun ne hakkında düşünmesi gerektiği konusunda başarı elde edebilmektedir (s. 13). Benzer şekilde McCombs ve Shaw (1972), medyanın belli haberleri sunarak, bazılarını gizleyerek ve benzer haberleri ön plana çıkartarak gündemi oluşturmasını inceleyerek Gündem Belirleme Kuramını² (Agenda Setting Theory) geliştirmişlerdir (s. 176). John R. Zaller (1992), medyanın insanların siyasal düşüncelerini etkileyebilme gücünün ${ }^{3}$ haberleri objektif bir şekilde vermesinden ziyade sürekli ve tutarlı bir şekilde yansıtmasından kaynaklandığını belirtmektedir. Ayrıca Michel Foucault’un (1981) da belirttiği gibi gündemi belirlemek üzere atılan manşetlerde kullanılan dil, kavram öbekleri, düzenli yayılım gösteren terimler belli bir amaca yönelik söylemleri de oluşturabilmektedir (s. 58). Dil ve iktidar arasındaki söylemsel ilişkiyi ele alan Eleştirel Söylem Analizi (ESA), Foucault ve Antonio Gramsci gibi dil, söylem ve iktidar arasındaki ilişkilere odaklanan düşünürler ile Frankfurt Okulu’na atfedilen eleştirel analizi birleştirerek dil ile söylem analizi arasındaki ilişkiyi ele almaktadır (Fairclough, 1992; Fairclough, 1995; Fairclough ve Wodak, 1997).

ESA’ya göre dilin söylem içindeki ve üzerindeki rolü ele alınmadan söylem ve toplum arasındaki karmaşı ilişki üzerine sosyolojik bir açıklama yapmak mümkün değildir. Bu bağlamda ESA, medyanın olayları objektif bir şekilde yansıtmak yerine hangi olayların nasıl ele alınacağına karar vererek kamuoyunda belirli olaylara karşı algı oluşturmaya çalışıp çalışmadığını sorgulamaktadır. ${ }^{4}$ Bunun yanında ESA, kamu politikaları süreçlerinin analizinden kamusal tartışmaların meşrulaştırılmasına kadar siyaset biliminin birçok alanında kullanılmaktadır. ESA aynı zamanda, milli kimlik tartışmalarının odağında yer alan dost/düşman ayrımına yol açan politik söylem analizinde de kullanılmaktadır (Blatter, Langer ve Wagemann, 2018, s. 123).

2 Alman aşırı sağının ve medyasının, siyasiler ve toplumda suçlu göçmen algısının oluşumuna dair etkisine yönelik bir inceleme için bkz. Tauscher (2017).

3 Basın sadece siyasal amaçlar üzerinden araçsallaştırılmamaktadır. Basın aynı zamanda, ticari amaçlar elde edilmesinde kullanılabildiği gibi parti grupları ya da sendikalar gibi toplumsal çıkar grupları tarafından da yönlendirilebilmektedir (Habermas, 2014, s. 305-309).

4 Medyada yayınlanan haberlerin izleyici üzerindeki etkisini anlamaya yönelik birçok modelleme yapılmıştır. Bunlar arasında, izleyicinin tamamen edilgen bir şekilde medya söylemini kabullendiği hipodermik model, izleyicilerin ihtiyaçları doğrultusunda medyayı takip ettikleri doyum modeli, insanların haberleri kültürel ve sınıfsal arka planları ile sorguladıkları alımla modeli ve izleyicinin farklı haber kaynakları karşılaştırarak irdelediği yorumlayıcı model bulunmaktadır (Giddens ve Sutton, 2013, s. 819-821). 
Medya, okuyucuların belirli bir yönde düşünmesine çabalar ve gazetelerde sıklıkla dile getirilen konular okuyucuların zihninde diğer konulara kıyasla daha kalıcı bir yer almaya başlar (Kim, Scheufeie ve Shanahan, 2002, s. 7-25). Özellikle günlük yaşantıda farklı kültürler ile çok fazla etkileşimin yaşanmadığı homojen toplumlarda grup dişllar ${ }^{5}$ hakkında yapılan olumsuz haberler, zihinlerde daha kalıcı bir yere sahip olurlar (van Dijk, 1989). Böylece medya, insanların derinlemesine bilgi sahibi olmadıkları ve araştırma yapmayacakları konular hakkında onların fikirlerinin şekillenmesinde önemli bir rol oynayabilmektedir. Bu duruma en güzel örneklerden biri, 2004 yılında Fransız Cumhurbaşkanı Jacques Chirac’n Türkiye’nin $A B$ üyeliğine ve bu tarihten sonraki olası her AB genişlemesine Fransảnın vereceği oyun referandumla belirleneceğini belirtmesinin ardından Fransız basınında hız kazanan Türkiye’ye dair haberlerdir. Beyza Çağatay Tekin $(2008 ; 2010)$ muhtelif çalı̧malarında, Fransız siyasetçilerin ve basının Türkiye’yi ötekileştirirken kullandığı kelime tercihleri üzerinden Türkiye’nin bir Avrupa ülkesi olmadığını göstermeye çalışan söylemi incelemektedir. Medyanın politik karar alma sürecinde görüş oluşturabilme kapasitesine dair yapılan araştırmalara diğer bir örnek olarak De Vreese ve Boomgaarden’in (2006) çalışması gösterilebilir. Bu çalışmaya göre medyanın AB’nin genişlemesini negatif veya pozitif olarak lanse etmesi halkta aynı görüşün yayılmasını sağlamaktadır (s. 419-436). Vatandaşların günlük hayatlarına dolaylı etkisi olacak AB’nin genişleme politikası gibi bir konuda dahi medyanın yönlendirici fikir oluşturabilmesi, halkı doğrudan ilgilendiren konularda algı oluşturmakta ne kadar başarılı olabileceklerinin bir göstergesidir.

Türkiye’nin AB’ye üye olma sürecinin yabancı ülke basınlarında ele alınışı birçok araştırmaya konu olmakla birlikte (Koening, Mihelj, Downey ve Gencel Bek, 2006; Madeker, 2008; Negrine, Kejanlioglu, Aissaoui ve Papathanassopoulos, 2008; Schneeberger, 2009; Aksoy, 2009; Walter ve Albert, 2009), Türkiyede yapılan genel seçimlerin yabancı ülke medyaları tarafından nasıl ele alındığına dair bir çalışmaya rastlanılmamıştır. Açıklandığı üzere medyanın söylem oluşturma gücü ve Türkiye’nin $\mathrm{AB}$ politikalarına görece uyumsuz politikaları dikkate alındığında, Türkiyede gerçekleşen 24 Haziran 2018 Genel Seçimleri’ne yönelik Alman basınında oluşturulan söylemin eleştirel bir analizi araştırma konusu bakımından anlamlıdır.

\section{Metodoloji}

Nitel araştırma tekniklerinin bir alanını oluşturan eleştirel söylem analizi yöntemine dair birçok önerme mevcuttur (Heiser, 2018; Lune ve Berg, 2017; Jäckle, 2017). Bu makale, bu önermelere dair bir tartışma yürütmekten ziyade Siegfried Jäger'in metodolojisini kullanacaktır. Jäger'in altı aşamalı ESA sistemini ${ }^{6}$ (Jäger, 2006, s. 102-106) kendisine örnek alan bu makalenin amac1, Almanyada dijital ortamda yayınlanan iki farklı ideolojik arka plana sahip Tageszeitung ${ }^{7}$ (taz) ve Süddeutsche

5 Teun A. van Dijk’’n "grup dıș” kullanımı, günümüzde akademide öteki kelimesinin kullanımına denk gelmektedir.

6 Jäger ESA sürecini, konunun tanıtımı ve temellendirilmesi (söylem dizisinin ortaya konulması), söylem düzeyinin belirlenmesi (dergi, gazete, konuşma metinleri, vb.), temel metinlerin hazırlanması ve geliştirilmesi, temel metinlerin söylem dizisi bağlamında değerlendirilmesi, benzer kalıpların detaylı analizi ve tekil sonuçların bir araya getirilerek söylem dizisi bağlamında genel analizinin yapılması olarak altı aşamaya ayırmaktadır.

7 Yayın hayatına 17 Nisan 1979 yılında 63.000 baskıyla başlayan ve 1995 yılında Almanyảnın dijital ortamda çıkan ilk günlük gazetesi olarak internette yayınlanan Tageszeitung, kendi açıklamalarına göre bağımsız ve sol bir günlük gazete olarak kurulmuştur ("Damals... Wie alles begann", 2018; "Die taz wird Genossenschaft", 2018.). Günümüzde dijital ortamda sayfa tıklanma sayıs (Page Impression) 11,75 milyon, ziyaret sayıs1 5,35 milyon ve her ay bu sayllara 1,49 milyon yeni kullanıcı eklenmektedir (“Wir über uns", 2018). 
Zeitung ${ }^{8}$ (SZ) gazetelerinin 24 Haziran 2018 tarihinde Türkiye’de yapılan genel seçimlere yönelik yayınladıkları haberleri eleştirel söylem analizine tabi tutmaktır. Bu sebeple, öncelikle iki yayın organında yayınlanan haberler belli kavramlar kullanılarak taramadan geçirilmiştir. Bulunan sonuçlardan araştırma konusuyla ilgili olan haberler ayıklanarak söylem için gerekli olan arşiv oluşturulmuştur. Her bir yayın organına ait haberler araştırma konusuna ait söylem dizisi dikkate alınarak değerlendirmeye tabi tutulmuştur. İki yayın organının söylem zincirlerinin birbirini takip eden, benzeşen ve farklılaşan yönleri, seçimlerin erkene alındığının beyan edildiği 18 Nisan 2018 ile seçim sonuçlarının kesinleştiği 26 Haziran 2018 genel seçim sürecinin, Türk demokrasisinin ve Türkiye’deki siyasal aktörlerin nasıl ele alındıkları ve bunlara hangi özelliklerin atfedildiği analiz edilerek sonuçlara ulaşılmıştır.

Haber kaynaklarının seçiminde ilk kriter olarak Almanya geneline hitap etmesi ve kendi ideolojik grubu tarafından ciddiyetle okunup takip edilmesi, aynı zamanda ülke çapında yayın yaparak Almanya toplumunun geneline ulaşabilme kapasiteleri olmuştur. İkinci kriter ise merkeze mesafeli sol gazete taz ve merkeze yakın sol liberal gazete $S Z$ gibi iki farklı ideolojik duruşu olan medya kuruluşlarının seçilmesiydi. Burada güdülen kaygı bir taraftan Türkiye'deki genel seçimler gibi tekil bir olguya farklı ideolojilerin ortak veya kendilerine özgü söylemlerinin olup olmadığının irdelenmesi isteği olmuştur. Diğer taraftan, Türkiye'deki genel seçimlerde öne çıan, CHP ile SZnnin ve HDP ile taz'ın kısmi de olsa ideolojik yakınlığının olduğu söylenebilecek yayın organlarının söylemlerini araştırmak arzusudur. Aşağıdaki tabloda da görüleceği üzere haber sitelerinde 13 anahtar kelime aratılmış ve 24 Haziran Genel Seçimleri’ni konu alan 84 haber bulunmuştur. Birbirinin tekrarı niteliğinde olan haberler ayrılarak haber sayısı 36’ya düşürülmüştür.

Tablo 1. Haber Sitelerinde Aratılan Anahtar Kelimeler

\begin{tabular}{|l|l|l|l|l|}
\hline \multirow{2}{*}{ ANAHTAR KELIME } & TAGESZEITUNG & & SUEDDEUTSCHE & \\
\cline { 2 - 5 } & Genel Haber Sayıs & Kullanılan Haber Sayıs & Genel Haber Sayısı & Kullanılan Haber Sayıs \\
\hline Türkei & 84 & 22 & 46 & 14 \\
\hline Türken & 53 & 22 & 16 & 14 \\
\hline Wahlen in der Türkei & 40 & 16 & 76 & 12 \\
\hline Opposition in der Türkei & 11 & 10 & 52 & 8 \\
\hline Recep Tayyip Erdoğan & 76 & 13 & 32 & 12 \\
\hline Muharrem İnce & 10 & 6 & 15 & 4 \\
\hline AKP & 25 & 6 & 22 & 8 \\
\hline CHP & 15 & 3 & 19 & 4 \\
\hline MHP & 4 & 2 & 11 & 2 \\
\hline HDP & 18 & 2 & 19 & 2 \\
\hline İYİ Parti & 4 & 3 & 9 & 2 \\
\hline Kemal Kılıçdaroğlu & 13 & 2 & 10 & 1 \\
\hline Meral Akșener & 4 & 3 & 8 & 1 \\
\hline Toplam & $\mathbf{8 4}$ & $\mathbf{2 2}$ & $\mathbf{7 6}$ & $\mathbf{1 4}$ \\
\hline
\end{tabular}

8 İkinci Dünya Savaşı’ndan sonra Bavyera Eyaleti’nde ilk basım lisansı alan gazetedir. 1945 yılında yayın hayatına başlayan gazete, 1995 yllında SZonNet ismiyle internette dijital olarak yayınlanmaya başlamıştır ("Geschichte des Süddeutschen Verlages", t.y.). Kendisini parti politikalarından ve sabit bir dünya görüşünden bağımsız olarak tanımlamakta, liberal ve hoşgörü temelinde, bireylerin bilgilendirilme ve serbestçe düşüncesini oluşturabilmesini görevi olarak görmektedir (“Unternehmensleitbild", t.y.). İnternette 81,2 milyon sayfa tıklanmasına, 27,4 ziyaretçiye ve 12,15 milyon yeni kullanıcıya ulaşmaktadır ("Die gesamte SZ im Netz", t.y.). 


\section{Söylem Analizi}

İki farklı yayın organı arasındaki ideolojik farklar basılı medyanın revaçta olduğu 1980'ler ve 1990’larda önemli rol oynamıştır. Medyanın dijitalleşerek ulaşılabilirliğinin artması ve maliyetlerin görece azalmasıyla haber içeriğinin çeşitlenmesi ve zenginleşmesi internet ortamında haberlere ulaşan okuyucu kitlesinin politik kimliğinin de çeşitlenmesine yol açmıştır. Ancak iki yayın organın da ideolojik arka planları haber seçimi ve haber içeriğinin işlenmesi bakımından halen etkilerini sürdürmektedir.

Bu bakımdan, öncelikle her bir haber kaynağının Türkiye’deki 24 Haziran Genel Seçimleri’ne dair yayınladıkları haberlerde kullandıkları dil, betimlemeler, fotoğraflar ve geliştirdikleri söylem dizisi ayrı ayrı incelenecektir. Daha sonra iki yayın organına ait ortak söylem dizileri ve ele alınışları irdelenecek, son olarak da birbirlerinden ayırt edici söylemleri detaylandırılmaya çalışılacaktır.

\section{Tageszeitung ve Veriler}

Anahtar kelimelerin aratılması sonucunda toplam 84 habere ulaşılmış, bunların Türkiye'deki genel seçimlerle doğrudan ilişkili 22'si çalışmaya konu olmuştur. Aşağıdaki tabloda taz’’n seçime yönelik söylemini oluşturan belli başlı veriler ayrıntılı olarak verilmiştir. Verilere göre iktidardaki AK Parti ve Cumhurbaşkanı Erdoğan’’n yer aldığı haberler başı çekmektedir. Arkasından HDP ve cumhurbaşkanı adayı Selahattin Demirtaş ile CHP ve Muharrem İnce'ye yönelik haberler gelmektedir. MHP, İyi Parti, Saadet Partisi ve Demokrat Parti gibi diğer muhalif partilerineyse görece daha az yer verilmektedir. Ancak yine de ileride görüleceği üzere $S Z$ 'da muhalif partilere yönelik yapılan haberlerden daha fazladır.

İktidar partisi ve Erdoğan’n haberlerin çoğunda yer almasına rağmen fotoğraflar ve haber içeriklerinde HDP ve Selahattin Demirtaşa ayrılan alan, kullanılan dil ve tanımlamaların yoğunluğu, taz gazetesindeki söylem dizisinin ana omurgasını HDP ve Demirtaş่ın oluşturduğunu göstermektedir. Özellikle Demirtaş่ın tutukluluğuna ve cezaevinde oluşuna yapılan sürekli vurgu, HDP’nin bir Kürt, kadın ve halk hareketi özelliği taşıdığının betimlenmesi ve haber içeriğinin daimi olarak HDP’nin politikaları veya Demirtaş่in söylevleriyle zenginleștirilmesi bahsedilen yoğunluğun sebepleridir. Arkasından daha az yoğunluklu olarak CHP ve Muharrem İnce’ye yönelik haber içerikleri gelmekte, kısttl olarak diğer muhalefet partileri ve liderlerine de yer verilmektedir. Tageszeitung'un haberlerinde yoğun olarak HDP ve Demirtaş’a ve bununla birlikte diğer muhalefet parti ve liderlerine de yer vermesi, gazetenin Türkiye'deki genel seçim sürecini muhalefet partileri ve adayları üzerinden okuduğunu göstermektedir. Erdoğan veya AK Partỉnin bulunduğu haberlerin "Diktatörlükten Önceki Son Çıkış", hatta Türkçe verilen "Dik DuracağıZ, AKP Gidecek"10 benzeri başlıklarla ya da içeriklerle iktidarın olumsuz betimlenmesi, bahsedilen okumayı destekler niteliktedir.

9 taz, Haber-5.

10 taz, Haber-7. 
Tablo 2: Tageszeitung’un Söylem Dizisini Oluşturan Veriler

\begin{tabular}{|c|c|c|c|c|c|c|c|c|c|}
\hline $\begin{array}{l}\text { Cumhurbaşkanı } \\
\text { Adayları Veya } \\
\text { Parti İsimlerinin } \\
\text { Geçtiği }\end{array}$ & $\begin{array}{l}\text { Ak Parti } \\
\text { ve Recep } \\
\text { Tayyip } \\
\text { Erdoğan }\end{array}$ & $\begin{array}{l}\text { CHP ve } \\
\text { Muharrem } \\
\text { İnce }\end{array}$ & $\begin{array}{l}\text { Saadet } \\
\text { Partisi }\end{array}$ & $\begin{array}{l}\text { HDP ve } \\
\text { Selahattin } \\
\text { Demirtaş }\end{array}$ & MHP & $\begin{array}{l}\text { İYI Parti } \\
\text { ve Meral } \\
\text { Akşener }\end{array}$ & $\begin{array}{l}\text { Demokrat } \\
\text { Parti }\end{array}$ & Diğer & Toplam \\
\hline Haber Sayısı & 7 & 4 & - & 6 & - & 2 & - & 3 & 22 \\
\hline $\begin{array}{l}\text { Toplam Haber } \\
\text { Sayısına Oranı }\end{array}$ & $\% 32$ & $\% 18$ & - & $\% 27$ & - & $\% 9$ & - & $\% 14$ & $\% 100$ \\
\hline Fotoğraf Sayısı & 3 & 4 & - & 6 & - & 2 & - & 5 & 20 \\
\hline $\begin{array}{l}\text { Toplam Fotoğraf } \\
\text { Sayısına Oranı }\end{array}$ & $\% 15$ & $\% 20$ & - & $\% 30$ & - & $\% 10$ & - & $\% 25$ & $\% 100$ \\
\hline $\begin{array}{l}\text { Fotoğraflardaki } \\
\text { Temsil }\end{array}$ & $\begin{array}{l}\text { Tek başına, } \\
\text { Otoriter, } \\
\text { Aksiyoner/ } \\
\text { güvenlikçi } \\
\text { bir duruş, }\end{array}$ & $\begin{array}{l}\text { Halk } \\
\text { desteğini } \\
\text { almış, } \\
\text { Sempatik } \\
\text { ve dini } \\
\text { motifler }\end{array}$ & - & $\begin{array}{l}\text { Yerel kıyafetli } \\
\text { kadınların ön } \\
\text { plana çıkması, } \\
\text { Mağdur, } \\
\text { Masum, } \\
\text { Mazlum, } \\
\text { Entelektüel bir } \\
\text { lider } \\
\end{array}$ & - & \begin{tabular}{|l} 
Coşkulu, \\
Halkla \\
bayraklar \\
eşliğinde iç \\
içe, \\
Aksiyoner ve \\
sempatik
\end{tabular} & - & $\begin{array}{l}\text { İktidar } \\
\text { karşıtı } \\
\text { gençler, } \\
\text { halk ve } \\
\text { kadınlar }\end{array}$ & \\
\hline Tanımlamalar & $\begin{array}{l}\text { İktidar, } \\
\text { Cumhur } \\
\text { başkanı, } \\
\text { Otoriter, }\end{array}$ & $\begin{array}{l}\text { Kemalistler, } \\
\text { Merkez Sol, } \\
\text { Sosyalist } \\
\text { Demokrat } \\
\text { Kemalistler, } \\
\text { Sol Ulusalcı } \\
\text { İnce: En } \\
\text { güçlü } \\
\text { muhalefet } \\
\text { adayı, } \\
\text { Tarafsız }\end{array}$ & İslamcı & \begin{tabular}{|l} 
Kürt Partisi, \\
Kürt Yanlısı, \\
Kürt Solu, \\
Kürt Sol \\
Partisi \\
Demirtaş: \\
Kürt Solcu, \\
Popüler, İyi bir \\
insan, Politik \\
rehine \\
PKK: Kürt \\
isyancllar, \\
Kürt Gerillası
\end{tabular} & $\begin{array}{l}\text { Cumhur } \\
\text { başkanı } \\
\text { Erdoğan’ın } \\
\text { küçük } \\
\text { ortağı, } \\
\text { Ultra Sağ }\end{array}$ & $\begin{array}{l}\text { Sağ } \\
\text { Muhafazakâr, } \\
\text { Milliyetçi }\end{array}$ & - & - & \\
\hline
\end{tabular}

Tageszeitung'un erken seçimin ilanından seçimlerin yapılmasına kadar geçen sürede; erken seçimin bir strateji olduğu, Türkiyedeki ekonomik durumun Erdoğan’ın tekrar seçilmesini zorlaştıracağı, HDP’nin adayı Demirtaş’ın tutuklu olması ve muhalefet adayları ile partilerini içeren dört farklı söylem dizisinden bahsedilebilir. Demirtaş'ın tutuklu olduğu haberler gibi bazıları sürekli gündeme getirilerek söylem dizisi haline gelmekte, diğer bazılarıysa haber sıklı̆̆ı daha az olmakla beraber haberin içeriğinin yoğunluğu ve söylemi oluşturan betimlemelerin ya da temsillerin kuvveti onları söylem dizisi olmaya aday yapmaktadır.

\section{Erken Seçim İlanı}

Türkiye'de erken seçimlerin ilan edildiği 18 Haziran 2018 günü taz'da, "Erdoğan’ın Dikkat Dağıtma Stratejisi” başlıklı bir haber yayınlanmıştır. Haberin okuyucuya ilk hitap ettiği alan Erdoğan'ın bulunduğu bir fotoğraf ve haber alt başlığıdır. Haberin alt başlığında verilen “Türkiye ekonomide ve dış ilişkiler konusunda düşüşe geçti. Kimse fark etmeden Cumhurbaşkanı hızlıca 
yeniden seçilmek istiyor" şeklindeki metin ve Erdoğan’ın arkasında kendisinin dev bir portresinin bulunduğu ve sol eliyle yön gösterdiği fotoğrafın altında "Kendi çıkarları peşinden gidebilmek için "Şu tarafa bak" diyerek dikkat dağıtılır" açıklaması, gazetenin Türkiyedeki erken seçimlerin nedenlerine yönelik söylemini ortaya koymaktadır. Haberin ilerleyen içeriğinde her ne kadar erken seçim teklifinin MHP lideri Devlet Bahçeli tarafından yapıldığı belirtilse de, erken seçim kararının muhalefeti hazırlıksız yakalamak ve ekonomi daha da kötüleşmeden seçilebilmek için Erdoğan tarafından alındığına dönük bir yazım göze çarpmaktadır. ${ }^{11}$ Burada dikkat çeken başka bir unsur ise taz ve $S Z Z^{12}{ }^{12}$ erken seçime dair yayınlanan iki haberde de yukarıda bahsedilen Erdoğan’ın aynı fotoğrafının kullanılmasıdır.

Erdoğan’n, erken seçim kararını muhalefeti hazırlıksız yakalamak için aldığına dair yapılan haberden yaklaşık bir ay sonra "Sağlam Duracağız, AKP Gidecek"13 başlığıyla muhalefete motivasyon niteliğinde yazım diline sahip Türkçe bir haber yayınlanmıştır. Haber, çoğunluğunu gençlerin oluşturduğu kalabalık bir grubun neşeli ve enerjik olarak yer aldığı bir fotoğraf eşliğinde verilmiştir.

\section{Ekonomik Kriz}

Türkiye'deki genel seçimler yaklaştıkça taz’ın haber içeriğinde ekonomik krize dair söylemler daha da belirginleşmeye başlamıştır. Özellikle öne çıkan üç haber gözükmektedir. İlki, "Saat Başı Kur Kaybı"14 başlıklı haberdir. Haberin kısa özetinin sunulduğu alt başlıkta yatırımcıların toplu halde Türkiye’yi terk ettikleri ve seçim öncesi ekonomik zayıflı̆̆ın Erdoğan’a zarar verebileceği yer almaktadır. Türk Lirasının saatlik olarak değer kaybettiğini, kurdaki artışın sonunda muhalefete iktidarın canını gerçekten acıtabileceği bir sebep verdiğini aktaran haberde, hükümete muhalif farklı bir internet gazetesi olan T24'ten bir yazarın "Lira Krizi, AKP iktidarının sonuna yaklaşıldığını göstermektedir." cümlesini alıntılayarak ekonomik kriz ile seçim arasında bağlantı kurulmaktadır. Ancak bunu daha önce "Sağlam Duracağız, AKP Gidecek" haberinde olduğu gibi farklı kişilerin dilinden yapmaktadır. Tageszeitung bu seferki haberinde Türkiye'deki ekonomik krize dair iktidara muhalif FOX kanalından, T24 internet gazetesinden ve sağ liberal Neuen Züricher Zeitung (NZZ) gazetesinden alıntılarla yapmaktadır.

Öne çıkan ikinci haber, aynı gün yayınlanan "Erdoğan Ekonomik Krizle Baş Başa"15 başlğı̆nı taşımaktadır. Alt başlı̆ında Erdoğan’’n ekonomik kriz ve anti-AKP ittifakından dolayı seçimi kaybedilebileceği belirtilen haber, Türkiye'deki inşaat sektörünün kötüye gittiği açlklamasıyla devam etmektedir. Sosyal demokrat-Kemalist olarak nitelendirilen CHP adayının büyük bir haber kanalına ilk defa ancak telefonla bağlanabildiği yer alan haberde, aynı zamanda emektar bir liberal olarak betimlenen T24 yazarı Hasan Cemal'in de düşüncelerini sadece internette açıklayabildiği belirtilmektedir. Ekonomik kriz söylemini desteklemek üzere bazı veriler verildikten sonra, NZZ gazetesinden alıntı yapılarak Türkiye’nin borçlarını ödeyemeyecek konuma gelmesinden dolayı yeni

11 taz, Haber-1.

12 SZ, Haber-1.

13 taz, Haber-7.

14 taz, Haber-11.

15 taz, Haber-12. 
bir küresel ekonomik krizin yaşanacağını aktarılmaktadır. Kendisini sol bir gazete olarak tanıtan taz, Türkiye’deki ekonomik krize dair yaptığı her iki haberde de sadece liberal kişilere değil sağ görüşe yakın bir gazeteden de haber alıntılamaktadır. Bu durum, araştırmanın başında da belirtildiği üzere medya organlarının tek bir ideolojik görüş üzerine haber yapmadıkları, belli politik duruşlarını destekleme/meşrulaştırmak için kendilerine zit görüş ve kişilerin söylemlerini de kendi söylemlerine eklemleyebildiklerini göstermektedir. Burada dikkat çeken husus ise, kullanılan yazı dilinin bağımsız olguları aktarmaktan ziyade iktidara karşı muhalefeti açıktan desteklemesi ve yer yer seçmenlere yönelik seçim stratejileri vermesidir. Özellikle sol bir Kürt partisi olarak nitelendirilen HDP’nin \%10'luk seçim barajını geçemediği takdirde AKP’nin 50-60 milletvekili daha fazla çıaracağı ve CHP yönetiminin HDP’nin barajı geçmesi için seçmenlerinin HDP’ye oy vermelerine karşı gelmediği yönündeki cümleler dikkat çekmektedir. Son olarak, Erdoğan’ın seçimleri kaybetmesi halinde seçimleri tanımayacağını ve kendisi yeniden seçilene kadar seçimleri tekrarlatabileceğini, iktidara muhalif Cumhuriyet gazetesini alıntılayarak vermektedir.

"Seçim Kampanyası Aracı Olarak Savaş"16 başlğını taşıyan üçüncü haberde ise salt ekonomik krize yer verilmemektedir. PKK’nın Kürt gerillaları olarak tanıtıldığı yazıda, Erdoğan’n ekonomik krize yönelik sorunları arka plana atmak üzere PKK’nın merkezi Kandil’e askeri operasyon düzenlediği yer almaktadır. Ancak yazının ilerleyen kısmında sadece bu tür önermeler bulunmamakta, PKK’nın Kandil'de yıllarca boşuna tutunmadığını, Kandil'e yapılacak operasyon sonucunda Irak'tan gelecek ölü asker ve sivil haberlerinin seçim kampanyasına zarar verebileceği gibi benzeri cümlelerle yazının dili gittikçe tehditkâr bir söyleme dönüşmektedir.

\section{Demirtaș ve Tutukluluk}

SZ'da hemen hemen hiç yer bul(a)mayan HDP’nin adayı Selahattin Demirtaş'in tutukluluk hali, taz'da Erdoğan'dan sonra en çok yer verilen konudur. Bunun önemli göstergelerinden biri, taz’ın, erken seçimin ilanından sonra Selahattin Demirtaş hakkındaki ilk haberini hem Türkçe hem de Almanca yapılmasıdır. Türkçe "Erdoğan’ın En Sevmediği Siyasetçi", Almanca ise "En Nefret Edilen Hasım" başlıklarıyla verilen haberlerin içerikleri ${ }^{17}$, ikinci haber içeriğinin daha uzun ve daha dramatik bir dille yazılması ${ }^{18}$ dışında birbirleriyle uyumludur. Ancak iki haber arasında yapılan yapısal değişiklik söylemin de farklılaşmasına yol açmaktadır. Türkçe haberde, Demirtaşıın "terör örgütü propagandası yapmaktan” dolayı ceza evinde olduğu açıklaması yapıldıktan sonra 7 Haziran

16 taz, Haber-16.

17 taz, Haber-3.

18 Örneğin; Türkçe haber içeriğinde Demirtaş’ın Edirne Cezaevi’nde kaldığı anlatılırken, Almanca haber içeriğinde aynı durum için "Hapishane Hücresi" (Gefängniszelle) ifadesi kullanılmıştır. Ayrıca Türkçe içerikle savcının Demirtaş’a yönelttiği suçlama "terör örgütü propagandası yapmak” olarak verilirken, Almanca haberde “yasadışı örgüt propagandası yapmak” (Propaganda für eine illegale Organisation) şeklinde verilmektedir. İki dildeki haber içeriklerinde kullanılan dilin farklılaşması sadece bunlarla sınırlı değildir. Almanca’da HDP, Kürt yanlısı sol parti (prokurdisch-linken HDP) olarak tanımlanırken, Türkçe haberde sadece HDP olarak verilmekte ve taz’ın sıklıkla yaptığı gibi HDP ve Demirtaş konuşturulurken Kürtlerin sözcüsü olarak sunulmaktadır. İki farklı dildeki iki farklı okuyucu kitlesine hitap eden haber içeriğinin belli yerlerde, özellikle Alman okuyucusunun Türk siyaseti hakkında daha az fikir sahibi olduğu önermesinden yola çıkılacak olunursa, daha ayrıntılı verilmesi doğaldır. Ancak her iki haber dili karşılaştırıldığında farklılaşmanın yukarıda da gösterildiği üzere söylemi oluşturan kilit kavramlarda meydana geldiği göze çarpmaktadır. 
2015 genel seçimlerinde Demirtaşıı "Seni Başkan Yaptırmayacağız" sloganına yer verilmektedir. Almanca haber içeriğinde ise, önce Demirtaş่ın sloganına yer verilmesi ve bu sloganın halkta karşıllık bularak AKP’nin tek başına iktidar olmasını engellediği anlatılmaktadır. Böylece haber içeriği olgusal olmaktan çok, Erdoğan’a yönelik "Seni Başkan Yaptırmayacağız" söyleminin halkta karşıllık bulmasından dolayı Demirtaş'ı̉n hapiste olmasına sebebiyet verdiği gibi bir söyleme dönüşmektedir. Türkçe haberde yer almayan "Bir Bahane Olarak Nevruz Kutlamalarındaki Konuşma" başlıklı son paragraf da bu söylemi destekler niteliktedir. Paragrafta, Demirtaş̉a yöneltilen suçlamalardan birinin, 17 Mart 2013 tarihinde İstanbul'da yaptığı bir konuşmada "yasadışı örgüt propagandası" yapmak olduğu belirtilmektedir.

Gazetelerin sadece olguları bildiren yayın organları olmadıkları aşikârdır. Editörler, köşe yazarları ve gazeteciler doğal olarak politik duruşlarını, dünya görüşlerini ve değerlerini yaptıkları haberciliğe katarak yazılarını hazırlamaktadır (Entman, 1989, s. 31). Böylece kişiler de kendi değerlerini yansıttıkları haber organlarını takip etmektedir. Ancak gazetecilerin kendi değerlerini habere katmaları belli başlı asgari gazetecilik normlarıyla yakından ilişkilidir. Söz konusu Türkiye ve HDP olduğu zaman taz’ın bu normların sınırında dolaştığ dikkat çekmektedir. Bu duruma örnek olarak "Diktatörlükten Önceki Son Çıkış"19 haberi verilebilir. HDP adayı Demirtaş่ı konuşturulduğu yazının giriş bölümünde, "Ya şimdi Erdoğan’ı düşürmeyi başarırız ya da on yıllık bir tek adam hâkimiyeti üzerimize gelecek" cümlesi doğrudan verilmektedir. Ancak bu cümlenin bir beyanatta mı yoksa röportajda mı verildiği okuyucuya aktarılmamaktadır. Ayrıca yazıyı kaleme alan yazar, bu açıklamayı yapan Demirtaş’n 24 Haziran Genel Seçimleri’ni kısa ve doğru olarak özetlediği yargısında bulunmaktadır. Yazının devamında, dört muhalefet partisinin birleşmesi, ekonomik kriz ve Demirtaş่ın sol seçmeni mobilize etmesiyle iktidardaki Erdoğan’ın devrilmesine dair umutlu bir strateji belirtilmektedir. Bunun yanında Demirtaş'la yapılan "Ben Politik Bir Rehineyim"20 başlıklı röportajın dili de yukarıda belirtilen duruma örnek gösterilebilir. Yapılan röportajda yöneltilen "Seçim sandıklarını olası sandık hilelerine karşı nasıl koruyacaksınız?” gibi sorular yargı barındırmaktadır.

\section{Fotoğraflar}

Erdoğan, az sayıda fotoğrafla birlikte verilmekte ve genellikle tek başına, yön gösterici, duruma hâkim fotoğrafları kullanılmaktadır. Bir iktidar partisi milletvekilinin Suruç’u ziyareti sırasında ölen üç kişinin anlatıldığı "Kürt Kasabasında Üç Ölü̈21 başlıklı yazıda kullanılan fotoğraf, arka planda kalan Erdoğan'dan ziyade, elinde ağır silahı bulanan bıyıklı bir güvenlik görevlisi ile Erdoğan’ın korumasına odaklanmaktadır. Böylece Erdoğan, ölümlerden dolayı doğrudan suçlanmamakla birlikte, yazıda verilen fotoğrafla sorumluluğun adresi olarak gösterilmektedir.

Tageszeitung, HDP ve Demirtaş'la ilgili yapılan haberlerde de iki ayrı yol izlemektedir. Haberlerin genellikle Demirtaş'la ilgili olduğu yerlerde mazlum, masum, tutuklu bulunmasına rağmen huzurlu, mağrur ve çok okuyan yalnız Demirtaş fotoğrafları kullanılmıştır. ${ }^{22}$ HDP ile ilgili haberlerdeyse

19 taz, Haber-5.

20 taz, Haber-8.

21 taz, Haber-20.

22 taz, Haber-3, 8. 
ellerinde ya da arka planda Demirtaş resimlerinin bulunduğu başı açık genç liberal ${ }^{23}$ ya da geleneksel Kürt yerel kıyafetleri içerisinde başörtülü kadın fotoğrafları ${ }^{24}$ yer almaktadır. Böylece sol Kürt hareketi olarak nitelendirilen HDP’nin içinde hem etnik unsurları hem de Batı'ya yakın liberal ve çağdaş kadını barındırdığı gösterilmektedir.

Diğer Cumhurbaşkanlığı adayları İnce ve Akşener fotoğraflarda genellikle arkalarında halk desteği görünen, dinamik ve sempatik olarak yer almaktadır. ${ }^{25}$ Ancak dikkat çeken bir husus İnce’nin sıklıkla dini motif ve söylemlerle haberleştirilmesidir. Örneğin; İnce’nin adaylığının duyurulduğu "Muharrem İnce CHP'den Aday Oluyor"26 başlıklı haberde "Tanrı̉nın izniyle ve milletin isteğiyle 24 Haziran’da Cumhurbaşkanı seçileceğim" cümlesi İnce’den alıntılanmaktadır. Hatta haberde yer alan "Tanrı̉nın izni" 27 ibaresi daha sonra İnce ile yapılan bir röportajın da başlı̆̆ı olmaktadır. Öyle ki, İnce’nin Yunanistan’a yaptığı bir ziyarete dair haberde, haberin içeriğinde yer almamasına rağmen İnce'nin bir kabristan ziyaretinde dua ederken çekilmiş fotoğrafı haberin görseli olarak yer almaktadır. ${ }^{28}$ Tageszeitung'un, Kemalist ve sosyal demokrat olarak tanımladığ 1 CHP’nin adayı İnce’ye, haber içeriklerinde ve görsellerde dini motiflerle yer verilmesi bir yandan İnce’nin seçim boyunca dini değerlere yaptığı pozitif atıflarla ilgilidir. Diğer taraftan ise, taz yazarlarının Cumhurbaşkanı adaylarını kategorileștirdikleri, AKP-İslamcı muhafazakâr, MHP-ultra sağcı, CHP-Kemalist ve sosyal demokrat, İYI Parti-sağ muhafazakâr ve HDP Kürt yanlısı sol benzeri sembollerle de alakalıdır. Haberlerde oluşturulan bu söylem göz önüne alındığında, HDP’nin solu temsil ettiği ve bu sebeple dini motiflerin onlara uzak olduğu söylenebilir. \%10'luk seçim barajının da etkisiyle sol seçmene, CHP’nin dini motifleri kullanan, sola uzak ve oy verilemeyecek bir parti olduğu, Kürt olmasalar da sol seçmene yönelik HDP’nin solu temsil ettiğgine dair bir söylem geliştirildiği gözlemlenmektedir.

\section{Sïddeutsche Zeitung ve Veriler}

Tageszeitung’a nazaran ideolojik olarak daha merkezde yer aldığı görülen $S Z$, konuyla ilgili daha az haber yayınlamıştır. İktidarda bulunmasından dolayı doğal olarak Erdoğan ve partisi haber sayısı bakımından başı çekmekle birlikte $S Z$ ikinci önceliği CHP ve adayı Muharrem İnce’ye vermiştir. $\mathrm{Bu}$ durum sadece aşağıdaki Tablo 3’ten okunabilen haber sayısıyla ilgili değildir. SZ, neredeyse Erdoğanın fotoğrafları kadar İnce’nin de fotoğraflarına yer vermiştir. Ayrıca CHP ve İnce ile ilgili haberlerin derinliği ve detaylı olması da göz ardı edilmemesi gereken bir husustur. Tageszeitung söylemsel ağırlığı HDP ve Demirtaş̉a verirken, SZ 24 Haziran Genel Seçimleri’ni CHP ve İnce üzerinden okumaktadır.

Erdoğan’la ilgili haberler genellikle erken seçim ilanı, seçim sırasında olağanüstü halin (OHAL) devamı ve Erdoğan’n Almanya'da olası bir seçim kampanyası yapmasının yasaklanması yönünde

taz, Haber-17, 18.

taz, Haber-5, 14, 19.

taz, Haber-2, 6, 9, 22.

taz, Haber-4.

taz, Haber-9.

taz, Haber-13. 
verilmiştir. Bunun yanında, "Erdoğan’ı Alt Etmesi Gereken Adam”29, “Savaşçı CHP Adayı Erdoğan’a Karşı Mücadeleye Giriyor”30 ve "Erdoğan’ın Rakibi İzmire Milyonları Çekiyor”31 gibi İnce’yle ilgili bazı haber başlıklarına bakıldığında, SZ’nin söylem dizisini kimin üzerinden oluşturduğu da ortaya çıkmaktadır. İnce’nin cumhurbaşkanlığı adaylığı resmileştikten sonra SZ'de çıkan haberlerin odağı, Almanyada seçim kampanyası yasağı, OHAL ve Erdoğan olmaktan çıkıp CHP'nin adayına yönelmektedir. Muhalefetteki diğer partilere ise CHP ile ittifaka yönelik haberlerde yer verilmekte, muhalefetin çatı adayı olmamasına rağmen haberlerden, Erdoğan’ın karşısındaki var olan muhalefet bloğunun tek adayının İnce olduğu genel izlenimi elde edilmektedir. Diğer muhalefet adaylarına oldukça az yer verilmesine rağmen Eski Cumhurbaşkanı Abdullah Gül'ün aday olmayacağı da kısıtlı haber sayısının arasında yer almıştır. "Erdoğan’a Karşı Bir Rakip Azaldı”32 başlıklı yazıda, Erdoğan’ın giderek otoriterleştiği belirtilirken, Gül'ün diyalog ve uzmanlaşmadan yana olduğu, olası adaylığının uzmanlar tarafından umut vaat edici olarak değerlendirildiği aktarılmaktadır. Öne çıkan bu başlıklarda da görüldüğü üzere kullanılan dil, fotoğrafların seçimi ve desteklenen adayın farklılaşmasına rağmen $S Z$ de söylemini Erdoğan’ın ve partisinin negatif bir dille haberleştirilerek eleştirilmesi ve Erdoğan’ın en ciddi rakibi görülen İnce’ye dair haberlerin pozitif aktarımı üzerine oluşturmaktadir.

Bu minvalde SZ’nin 24 Haziran Genel Seçimleri’ne yönelik haberleri incelendiğinde üç söylem dizisinin öne çıktığı görülmektedir. İlk söylem dizisi, muhalifleri hazırlıksız yakalamak ve böylece onlara karşı üstünlük sağlamak amacıyla Erdoğan tarafından erken seçim kararı alınmasıdır. 18 Nisan'da verilen erken seçim kararı haberinden bir gün sonra, Erdoğan’ın Almanyada seçim çalışması yapmasına izin verilip verilmeyeceği yönünde Dışişleri Bakanı Heiko Mass’ın, 22 Haziran’da Türk siyasetçilerinin Almanya'da propaganda yapamayacakları yönündeki açıklamasına kadar seri halde yayınlanan yazılar ikinci söylem dizisini meydana getirmektedir. Üçüncü söylem dizisini ise Türkiye'deki mevcut OHAL durumu oluşturmaktadır.

Tablo 3: Süddeutsche Zeitung'un Söylem Dizisini Oluşturan Veriler

\begin{tabular}{|l|l|l|l|l|l|l|l|l|l|}
\hline $\begin{array}{l}\text { Cumhurbaşkanı } \\
\text { Adayları Veya Parti } \\
\text { İsimlerinin Geçtiği }\end{array}$ & $\begin{array}{l}\text { Recep Tayyip } \\
\text { Erdoğan }\end{array}$ & $\begin{array}{l}\text { Muharrem } \\
\text { İnce }\end{array}$ & $\begin{array}{l}\text { Saadet } \\
\text { Partisi }\end{array}$ & $\begin{array}{l}\text { HDP ve } \\
\text { Selahattin } \\
\text { Demirtaş }\end{array}$ & MHP & $\begin{array}{l}\text { IYI Parti } \\
\text { ve Meral } \\
\text { Akşener }\end{array}$ & $\begin{array}{l}\text { Demokrat } \\
\text { Parti }\end{array}$ & Diğer & Toplam \\
\hline Haber Sayısı & 9 & 3 & 1 & - & - & 1 & - & - & 14 \\
\hline $\begin{array}{l}\text { Toplam Haber } \\
\text { Sayısına Oranı }\end{array}$ & $\% 64$ & $\% 22$ & $\% 7$ & - & - & $\% 7$ & - & - & $\% 100$ \\
\hline Fotoğraf Sayısı & 5 & 4 & - & - & - & 1 & - & 1 & 11 \\
\hline $\begin{array}{l}\text { Toplam Fotoğraf } \\
\text { Sayısına Oranı }\end{array}$ & $\% 46$ & $\% 36$ & - & - & - & $\% 9$ & - & $\% 9$ & $\% 100$ \\
\hline
\end{tabular}

$29 S Z$, Haber-10.

$30 S Z$, Haber-11.

$31 S Z$, Haber-13.

32 SZ, Haber-8. 


\begin{tabular}{|c|c|c|c|c|c|c|c|c|}
\hline $\begin{array}{l}\text { Fotoğraflardaki } \\
\text { Temsil }\end{array}$ & $\begin{array}{l}\text { Ciddi, } \\
\text { Tek başına, }\end{array}$ & \begin{tabular}{|l|} 
Coşkulu, \\
Halk \\
desteğini \\
arkasına \\
almış, \\
Tarafsız \\
başkan \\
adayl, \\
Hesap \\
soran
\end{tabular} & - & - & - & & - & \\
\hline Tanımlamalar & $\begin{array}{l}\text { İslami } \\
\text { Muhafazakâr, } \\
\text { Otoriter, } \\
\text { Otokrat }\end{array}$ & $\begin{array}{l}\text { Sosyal } \\
\text { demokrat, } \\
\text { Kemalist }\end{array}$ & $\begin{array}{l}\text { İslamc1 } \\
\text { Parti }\end{array}$ & $\begin{array}{l}\text { Kürt } \\
\text { yanlıs1, } \\
\text { Kürt Partisi }\end{array}$ & $\begin{array}{l}\text { Aşırı } \\
\text { Milliyetçi, } \\
\text { Ultra } \\
\text { milliyetçi, } \\
\text { Kral } \\
\text { yaratan } \\
\text { adam }\end{array}$ & $\begin{array}{l}\text { Milliyetçi } \\
\text { Muhafazakâr, } \\
\text { Sağcı } \\
\text { Muhafazakâr, } \\
\text { Sabit fikirli }\end{array}$ & - & \\
\hline
\end{tabular}

\section{Erken Seçim Kararı}

SZ’de de çıkan haberlerin genelinde erken seçim konusunda yönlendirici yegâne kişinin, "Erdoğan Türkiye'de Erken Seçim İstiyor”33 başlıklı yazının manşetinden de anlaşılacağı üzere Erdoğan olduğu okuyucuya aktarılmaktadır. Haber içeriğinde önerinin Bahçeli tarafından yapıldığı çok sonraları yer almaktadır. Haber içeriğinde, Alman Meclis Başkan Yardımcısı ve Yeşiller Partisi’nden Claudia Roth ve Hristiyan Demokrat Partisi'nden Jürgen Hardt konuşturularak OHAL’in devamı ve erken seçim kararının otoriter şekilde Erdoğan tarafından alınmasına karşın Almanya’nın yaptırımda bulunması gerektiği üzerine odaklanılmaktadır. Ertesi gün yayınlanan diğer bir haberde ise Bahçeli'nin erken seçimi talep etmesinin şüpheli bir koreografi gibi gözüktüğü, kararın Erdoğan tarafından alındığ 1 değerlendirilmesinde bulunulmaktadır. Aynı haberde iktidara muhalif bir gazeteden alıntı yapılarak erken seçimin “baskın seçim” kararı olduğu aktarılmaktadır. Abdullah Gül, Meral Akşener ve Kemal Kılıçdaroğlu gibi olası adayların tanıtıldığı ve HDP’nin önemli isimlerinin tutuklu bulunduğu aktarılan yazıda Muharrem İnce’nin adı geçmemektedir. ${ }^{34}$

Seçimleri Erdoğan’n erkene aldırdığ $1^{35}$ ve erken seçim kararıyla muhalefeti gafil avlamak istediği ${ }^{36} S Z$ 'de seçim dönemi boyunca devam eden söylemlerden biridir. Tageszeitung, erken seçim kararını olası ekonomik krizle bağdaştırırken $S Z$ erken seçim kararını Erdoğan’ın muhalifleri “baskın seçim” ilanıyla gafil avlamak istemesiyle ilişkilendirmektedir.

$\begin{array}{ll}33 & S Z \text {, Haber-1. } \\ 34 & S Z \text {, Haber-3. } \\ 35 & S Z \text {, Haber- } 9 . \\ 36 & S Z \text {, Haber-4. }\end{array}$




\section{Seçim Kampanyası Yasă̆ı}

Tageszeitung'da yer almayan Türk siyasetçilerinin Almanya’da seçim çalışması yapıp yapamayacakları, $S Z$ için Türkiye’de seçimlerin erkene alınmasının yanında diğer önemli gündem maddelerinden birini oluşturmaktadır. Erken seçim kararının hemen arkasından "Türk Siyasilerin Almanya'daki Seçim Kampanyaları Hakkında Yeni Ayaklanma" ${ }^{37}$ başlıklı bir yazı kaleme alınmıştır. Zamanın Başbakanı Erdoğan’’n konuşması için bir spor salonuna gelen kalabalığın ve başörtülü kadınların ön planda bulunduğu fotoğrafla birlikte yayınlanan haberde, CDU Genel Sekreteri Annegret Kramp-Karrenbauer ve Sosyal Demokrat Partili Burkhard Lischka gibi birçok Alman politikacının olası bir seçim kampanyasına karşı oldukları belirtilmektedir.

Türk siyasileri adı altında Erdoğan’n Almanya’da düzenleyeceği olası bir seçim kampanyasının demokrasi, hukuk, adalet ve benzeri kavramlarla irtibatlanması sadece yukarıdaki habere özgü değildir. "Acilen Hayır Denmeli”"38 başlığıyla çıkan yazıda, Erdoğan’ın yargı kurumuna ${ }^{39}$ ve gazetecilere tutumunun ${ }^{40}$ anayasaya aykırı olduğu, bu sebeple de Almanya topraklarının Erdoğan tarafından propaganda sahnesi olarak istismar edilmemesi çağrısı yapılmaktadır. Militan demokrasinin "deliye tanınan özgürlük" anlamına gelmediği, toplumsal barışın, hukuk devletinin, insan haklarının ve demokrasinin korunması adına Türk Cumhurbaşkanına sınırlamalar getirilmesi gerektiği oldukça ciddi ve talepkâr bir şekilde belirtilmektedir. Kullanılan dil ve üslup yazıyı ideolojik bir manifestoya çevirmektedir. Dışişleri Bakanı Maas’ın, ülkelerindeki seçimlere üç aydan az süre kalan, $A B$ üyesi olmayan üçüncü ülke siyasetçilerine Almanyada seçim kampanyası yürütme yasağı getiren düzenlemeyi yinelemesi üzerine ${ }^{41}$, $S Z$ de bu konuyla ilgili doğrudan haberler aniden kesilmiştir. Bu gelişme, medyanın söylemiyle oluşan gündemin, siyasetçileri nasıl etkilediğine dair önemli bir medya performansını da ortaya çıkarmaktadır.

\section{Olă̆anüstü Hal}

$S Z$, Türkiye'de erken seçim ilanının yapıldığı gün yayınladığı haberinde Türkiye’nin siyasi durumuyla ilgili önemli bilgiler de vermektedir. Bu bilgiler arasında siyasi koalisyonların ve olası ittifakların aktörlerine dair bilgiler bulunduğu gibi OHAL’in, Türkiye'de yaşanan bir askeri darbe girişimi sonrasında ilan edildiğine dair de bilgiler de mevcuttur. Bunun yanında, Alman Meclis Başkan Yardımcısı ve Yeşiller Partisi üyesi Claudia Roth ve Hristiyan Demokrat Partisiden Jürgen Hardt alıntılanarak OHAL'in devam etmesi halinde Alman Devleti’nin Türkiye'ye yaptırımlar uygulaması gerektiği aktarılmaktadır. Bu gibi başkalarına atıfla yönlendirici haberciliği bir önceki inceleme konusu olan taz'da da görmek mümkündür. Tageszeitung, genellikle Türkiye’den kişi ve yayın organlarına atıf yaparken $S Z$ daha ziyade Alman ya da Avrupalı siyasetçilere ve kurumlara söz vermekte ya da "Acilen Hayır Denmeli”" ${ }^{2}$ başlıklı yazıda olduğu gibi onlara hitap etmektedir.

37 SZ, Haber-2

$38 S Z$, Haber-4.

39 Yargı kurumuna yönelik ayrıntılı bir haber için bkz. SZ, Haber-12.

40 Medya ve gazetecilere yönelik yayınlanan başka bir haber için bkz. SZ, Haber-13.

41 SZ, Haber-6.

$42 S Z$, Haber-4. 
Bir gün sonraki haberde ${ }^{43}$ de OHAL'e yer verilmekte, CHP’li bir politikacıya atıf yapılarak OHAL durumunda adaletli bir seçimin yapılamayacağı aktarılmaktadır. Devamında bir Avrupa kurumu olan AB Komisyonu'na atfen, komisyonun Türkiye raporunda OHAL durumunun ciddi şekilde eleştirildiği ve OHAL’in kaldırılmasının talep edildiği belirtilmektedir. ${ }^{44}$ İki saat sonra yayınlanan başka bir yazıda "OHAL Cumhurbaşkanına Yardımcı Olacak" alt başlığıyla birlikte Türkiye’deki OHAL durumuna daha fazla yer ayrılmıştır. Ayrıca yazıda, neden tutuklu bulunduklarına dair hiçbir ayrıntı verilmeden Kürt yanlısı olarak nitelenen HDP genel başkanının ve önemli kurmaylarının hapiste oldukları belirtilerek Erdoğan’ın kaybetmesinin, rakiplerinin hızlı organize olup olamamalarına bağlanmaktadır. Yazı boyunca, Türk siyasi gündeminin olgusal tarifinden ziyade belli konuları kanıtlar ve arka plan bilgileri verilmesi yerine her şeye gücü yeten ve kontrol edebilen negatif bir Erdoğan portresinin çizilmesi tercih edilmiştir.

19 Nisan'da OHAL'in yedinci kez üç aylık bir dönem için uzatılmasının arkasından SZ'de OHAL'le doğrudan ilişkili haberlere son verilmiştir. Aynı durum Türk siyasilerin Almanya'da seçim kampanyası yapmamalarına yönelik çıkan haberlerde de yaşanmış, dışişleri bakanı Maas’ın Alman hükümetinin yasağı işletmeye kararlı olduğu yönündeki açıllamasıyla $S Z$, bu konuda benzer haberler yapmayı bırakmıştır. Seçim kampanyası konusunda oluşturduğu gündem $S Z$ açısından olumlu sonuçlanırken, OHAL'in devam etmesi halinde Alman devletinin Türkiye’ye yaptırımlar uygulanması yönündeki gündem oluşturma çabası sonuçsuz kalmıştır.

\section{Fotoğraflar}

Haber sayısının azlığına bağlı olarak fotoğrafların sayısı da taz'dakilere nazaran daha azdır. Ancak SZ'de farklı olarak sadece Erdoğan, İnce, Akşener ve Güle yer verilmiş, Demirtaş่ın ise fotoğrafı kullanılmamıştır. SZ'nin hedef kitlesine uygun olarak kullanılan fotoğraflarda da sıradan halk yerine parti liderlerine yer verilmiştir. ${ }^{45} \mathrm{Bu}$ fotoğraflarda dikkat çeken önemli unsurlardan biri, taz ve $S Z$ 'nin 18 Nisan tarihli erken seçim haberlerinde Erdoğan’ın birebir aynı fotoğrafını kullanmasıdır. Erdoğan, kullanılan diğer fotoğraflarında ya yalnız ya da çevresinde bulunan az sayıdaki insandan tecrit ve özgüvenlidir. Erdoğan ve partisinin öne çıktığı ve Türk siyasilerin Almanya’da seçim kampanyası yapmaması ile ilgili bir haberde kullanılan fotoğrafta, bir spor salonu dolusu insan gösterilmekte, ancak görselin odağında başörtülü kadınlar bulunmaktadır. Muharrem İnce’nin yer aldığı haberlerde ise, Erdoğanın aksine hem hesap soran, yalnız ve ciddi bir kişilik olarak hem de arkasında kimi zaman parti üyelerinin kimi zaman halkın desteğinin olduğunu anlatan kalabalıkların önünde lider pozisyonunda bulunduğu fotoğraflar seçilmiştir.

\footnotetext{
$43 S Z$, Haber-3.

44 SZ, Haber-2.

45 Tageszeitung analizinin fotoğraflar kısmında da belirtildiği üzere çok sayıda daha az “önemli” sıradan halkın fotoğraflarına yer verilmiştir.
} 


\section{Sonuç}

Araştırmanın başından itibaren her bir yayın organı hem kendi haber dili ve söylem dizisi üzerinden hem de karşılaştırmalı olarak analiz edilmiştir. Her yayın organı haber içeriklerini kendi ideolojik duruşu ile hitap ettiği ve etkilemek istediği okuyucu kitlesine göre düzenlemektedir. Farklı iki ideolojiye sahip taz ve $S Z$, yayınlarında farklı kişi ve kurumları söylemlerinin odağına almakta ve öne çıkarmaktadır. Bu durum taz'da Demirtaş ve HDP’nin öne çıkmasına yol açarken, SZ'de İnce ve CHP’nin odak noktasında yer almasını sağlamaktadır. Ancak iki yayın organın söylemlerinde ortak olan yegâne unsur Cumhurbaşkanı Erdoğan’a yöneltilen otoriterlik, insan hakları ihlalleri, tek adam iktidarı, hukuk sınırları dışına çıkma, demokrasiden uzaklaşma gibi suçlamalar ve yakıştırılan sıfatlardır. İncelemeye konu olan yayın organları için “dış öteki”yi, Erdoğan ve onun politikaları oluşturmaktadır. Erdoğan karşıtlığında ideolojilerinin farklılığına rağmen ortak bir dil ve söylem geliştirebilen iki kurum, destekledikleri muhalif hareketlerde ideolojik yönlerini ortaya koymaktadır. Ancak burada şaşırtıcı bir unsur etnik milliyetçiliği dışlayan enternasyonal bir ideolojiye mensup taz'ın Kürt yanlısı ${ }^{46}$, Kürt Solu Partisi ${ }^{47}$ olarak tanımladığı etnik milliyetçiliğe dayalı bir partiyi söyleminin merkezine pozitif olarak almasıdır. Benzer şekilde Avrupa Birliği Bakanlar Konseyi kararıyla $^{48}$ terör listesine alınmış PKK Terör Örgütü mensuplarına taz'da Kürt gerillası ${ }^{49}$ olarak yer verilmektedir. Böylece, bir yandan Türkiye'de siyasi durumun Avrupa değerlerine ve AB normlarına aykırı bir yönde seyrettiği yönünde yargı içeren haberlere yer verilirken, diğer yandan AB’nin en üst kurumlarından birinin aldığg karar görmezden gelinmektedir. Tageszeitung, Türkiye'deki duruma yönelik haber yaparken, $S Z$ daha politik söyleme girerek Alman hükümetinden, Türk siyasilerinin Almanya'da seçim kampanyası yürütmelerinin engellenmesini doğrudan talep etmektedir.

Türkiye’ye yönelik haberler irdelendiğinde dikkat çeken bir diğer nokta ise, taz’’n hedef kitlesinin çoğu zaman Türkçe okuyabilenler de dâhil genel okuyucu kitlesi iken, SZ'nin hedef kitlesinin daha çok politika yapıcılar ve siyasi kurumlar olduğu görülmektedir. Tageszeitung, haberlerinde yayın kurulunun gözlügüüle de olsa okuyucuyu bilgilendirmeyi amaçlarken, SZ’nin daha çok politik gündem yaratıp siyasileri politik konularda yönlendirmeye çalıştığı gözlemlenmektedir. Her iki gazetenin de ortak olduğu nokta Erdoğan karşıtlı̆̆ıdır. Destekledikleri adaylar konusunda ise taz'da HDP ve Demirtaş ön plana çıkarken, SZ'de, CHP ve İnce’nin adaylığı önemli yer bulmaktadır. Seçim sürecine yaklaşımları ise birbirinden oldukça farklıdır. SZ için OHAL durumunun devam etmesi ve seçim kampanyası yasağı en önemli söylemi oluştururken, taz ekonomik kriz ve Demirtaş’n tutuklu olması üzerinden söylemini kurmaktadır.

Bu veriler ışığında değerlendirilecek olursa, gündemi oluşturmaya gayret eden yayın organlarının objektiflik bir yana kendi ideolojik duruşları ve yayın ilkeleri doğrultusunda bile habercilik yap(a) madıkları gözlenmektedir. Alman siyasi hayatında popüler hale gelen Müslüman ve Erdoğan karşıtlı̆̆1 farklı kutuplardaki medya organlarını birleştiren yegâne unsur olarak ortaya çıkmaktadır. Böylece halen aydınlanmanın evrensel ilkelerini savunduğunu iddia eden kişi ve kurumların, konjonktürel

\footnotetext{
46 taz, Haber-8.

47 taz, Haber-17.

48 Kararın tam metni için bakınız; "Bechluss (GASP) 2017/1426 DES RATES vom 4. August 2017", 2017.

49 taz, Haber-16.
} 
etkilerle nasıl kolayca dost/düşman ayrımına giderek ötekinin karşısında konumlandırdıkları

görüşlerini homojenleştirdikleri görülmektedir.

\section{Tageszeitung Haber Listesi}

\begin{tabular}{|c|c|c|c|}
\hline $\begin{array}{l}\text { Haber } \\
\text { No }\end{array}$ & Başlık & Tarih & Erişim Linki \\
\hline 1 & Erdoğans Ablenkungsstrategie & 18.04 .2018 & $\begin{array}{l}\text { https://www.taz.de/Archiv-Suche/!5497090\&s=T\%C3\%BCrkei } \\
\% 2 \mathrm{Bt} \% \text { C3\%BCrkei/ }\end{array}$ \\
\hline 2 & $\begin{array}{l}\text { Kemalisten kuscheln mit } \\
\text { Nationalisten }\end{array}$ & 23.04 .2018 & $\begin{array}{l}\text { https://www.taz.de/Archiv-Suche/!5500897\&s=T\%C3\%BCrkei } \\
\% 2 \mathrm{Bt} \% \text { C3\%BCrkei// }\end{array}$ \\
\hline 3 & Der meistgehasste Widersacher & 30.04 .2018 & $\begin{array}{l}\text { https://www.taz.de/Archiv-Suche/!5502244\&s=T\%C3\%BCrkei } \\
\% 2 \mathrm{Bt} \% \text { C3\%BCrkei/ }\end{array}$ \\
\hline 4 & $\begin{array}{l}\text { Muharrem İnce tritt für die CHP } \\
\text { an }\end{array}$ & 04.05 .2018 & $\begin{array}{l}\text { https://www.taz.de/Archiv-Suche/!5503603\&s=T\%C3\%BCrkei } \\
\text { \%2Bt\%C3\%BCrkei// }\end{array}$ \\
\hline 5 & Letzte Ausfahrt vor der Diktatur & 06.05 .2018 & $\begin{array}{l}\text { https://www.taz.de/Archiv-Suche/!5500668\&s=T\%C3\%BCrkei } \\
\% 2 \mathrm{Bt} \% \mathrm{C} 3 \% \text { BCrkei/ }\end{array}$ \\
\hline 6 & Opposition bildet Parteienallianz & 06.05 .2018 & $\begin{array}{l}\text { https://www.taz.de/Archiv-Suche/!5503697\&s=T\%C3\%BCrkei } \\
\% 2 \mathrm{Bt} \% \text { C3\%BCrkei/ }\end{array}$ \\
\hline 7 & Sağlam duracağız, AKP gidecek & 08.05 .2018 & $\begin{array}{l}\text { https://www.taz.de/Archiv-Suche/!5503624\&s=Tunca\%2B\%C3 } \\
\% 96 \% \text { C4\%9Freten/ }\end{array}$ \\
\hline 8 & Ich bin eine politische Geisel & 08.05 .2018 & $\begin{array}{l}\text { https://www.taz.de/Archiv-Suche/!5501487\&s=T\%C3\%BCrkei } \\
\% 2 \mathrm{Bt} \% \text { C3\%BCrkei/ }\end{array}$ \\
\hline 9 & "Mit Gottes Erlaubnis" & 23.05.2018 & $\begin{array}{l}\text { https://www.taz.de/Archiv-Suche/!5507354\&s=T\%C3\%BCrkei } \\
\% 2 \mathrm{Bt} \% \mathrm{C} 3 \% \text { BCrkei/ }\end{array}$ \\
\hline 10 & Schalt den Fernseher aus & 24.05.2018 & $\begin{array}{l}\text { https://www.taz.de/Archiv-Suche/!5508124\&s=T\%C3\%BCrkei } \\
\% 2 \mathrm{Bt} \% \mathrm{C} 3 \% \text { BCrkei/ }\end{array}$ \\
\hline 11 & Kursverluste im Stundentakt & 24.05 .2018 & $\begin{array}{l}\text { https://www.taz.de/Archiv-Suche/!5508104\&s=T\%C3\%BCrkei } \\
\% 2 B w a h l e n /\end{array}$ \\
\hline 12 & \begin{tabular}{|l} 
Erdoğan kriegt die \\
Wirtschaftskrise
\end{tabular} & 24.05.2018 & $\begin{array}{l}\text { https://www.taz.de/Archiv-Suche/!5504443\&s=T\%C3\%BCrkei } \\
\% 2 \mathrm{Bt} \% \text { C3\%BCrkei/ }\end{array}$ \\
\hline 13 & $\begin{array}{l}\text { Griechenlands Angst vorm } \\
\text { Nachbarn }\end{array}$ & 04.06 .2018 & $\begin{array}{l}\text { https://www.taz.de/Archiv-Suche/!5507640\&s=T\%C3\%BCrkei } \\
\% 2 B c h p /\end{array}$ \\
\hline 14 & Aus der Kantine ins Parlament & 05.06 .2018 & $\begin{array}{l}\text { https://www.taz.de/Archiv-Suche/!5510918\&s=T\%C3\%BCrkei } \\
\% 2 \mathrm{Bt} \% \text { C3\%BCrkei/ }\end{array}$ \\
\hline 15 & Erdoğan ist kein frommer Mann & 06.06 .2018 & https://gazete.taz.de/article/?article=!5509854 \\
\hline 16 & Krieg als Mittel im Wahlkampf & 06.06 .2018 & $\begin{array}{l}\text { https://www.taz.de/Archiv-Suche/!5507860\&s=T\%C3\%BCrkei } \\
\% 2 \mathrm{Bt} \% \text { C3\%BCrkei// }\end{array}$ \\
\hline 17 & $\begin{array}{l}\text { Kurdischer Stachel in Erdoğans } \\
\text { Fleisch }\end{array}$ & 08.06 .2018 & https://www.taz.de/Archiv-Suche/!5509039\&s=t\%C3\%BCrkei/ \\
\hline 18 & Auf Stimmenfang gegen Erdoğan & 10.06 .2018 & https://www.taz.de/Archiv-Suche/!5511940\&s=t\%C3\%BCrkei/ \\
\hline 19 & $\begin{array}{l}\text { Die Stimmen, die entscheiden } \\
\text { werden }\end{array}$ & 15.06 .2018 & https://www.taz.de/Archiv-Suche/!5510798\&s=t\%C3\%BCrkei/ \\
\hline 20 & Drei Tote in kurdischer Kleinstadt & 15.06 .2018 & https://www.taz.de/Archiv-Suche/!5510803\&s=t\%C3\%BCrkei/ \\
\hline 21 & Wollt ihr zurück zur alten Türkei? & 15.06 .2018 & https://www.taz.de/Archiv-Suche/!5513298\&s=t\%C3\%BCrkei/ \\
\hline 22 & Schnauzbart gegen Vollbart & 20.06 .2018 & https://www.taz.de/Archiv-Suche/!5514947\&s=wahlen/ \\
\hline
\end{tabular}


Süddeutsche Zeitung Haber Listesi

\begin{tabular}{|c|c|c|c|}
\hline $\begin{array}{l}\text { Haber } \\
\text { No }\end{array}$ & Başlık (Türkçe-Almanca) & Tarih & Erişim Linki \\
\hline 1 & $\begin{array}{l}\text { Erdogan will vorgezogene Wahlen } \\
\text { in der Türkei }\end{array}$ & 18.04 .2018 & $\begin{array}{l}\text { http://www.sueddeutsche.de/news/politik/wahlen-erdogan- } \\
\text { will-vorgezogene-wahlen-in-der-tuerkei-dpa.urn-newsml-dpa- } \\
\text { com-20090.101.180418-99-947580 }\end{array}$ \\
\hline 2 & $\begin{array}{|ll|}\text { Neue Unruhe } & \text { um Wahlkampf } \\
\text { türkischer } & \text { Politiker in } \\
\text { Deutschland } & \end{array}$ & 19.04.2018 & $\begin{array}{l}\text { http://www.sueddeutsche.de/news/politik/konflikte-neue- } \\
\text { unruhe-um-wahlkampf-tuerkischer-politiker-in-deutschland- } \\
\text { dpa.urn-newsml-dpa-com-20090.101.180419-99-966122 }\end{array}$ \\
\hline 3 & Erdoğans Gegner straucheln & 19.04 .2018 & $\begin{array}{l}\text { http://www.sueddeutsche.de/politik/tuerkei-erdoans-gegner- } \\
\text { straucheln-1.3951514 }\end{array}$ \\
\hline 4 & Nein tut not & 20.04 .2018 & $\begin{array}{l}\text { sueddeutsche.de/politik/erdoan-nein-tut- } \\
0\end{array}$ \\
\hline 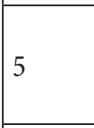 & $\begin{array}{l}\text { Erdogan: Ausnahmezustand } \\
\text { könnte bis nach Wahlen andauern }\end{array}$ & 21.0 & $\begin{array}{l}\text { http://www.sueddeutsche.de/news/politik/wahlen-erdogan- } \\
\text { ausnahmezustand-koennte-bis-nach-wahlen-andauern-dpa. } \\
\text { urn-newsml-dpa-com-20090.101.180421-99-991241 }\end{array}$ \\
\hline 6 & $\begin{array}{l}\text { Erdogan will Wahlkampf im } \\
\text { Ausland - Maas bekräftigt Verbot }\end{array}$ & 22.04 & $\begin{array}{l}\text { http://www.sueddeutsche.de/news/politik/konflikte-erdogan- } \\
\text { will-wahlkampf-im-ausland--maas-bekraeftigt-verbot-dpa. } \\
\text { urn-newsml-dpa-com-20090.101.180422-99-04033 }\end{array}$ \\
\hline 7 & $\begin{array}{l}\text { Türkischer Außenminister will } \\
\text { offenbar Rede in Solingen halten }\end{array}$ & 23.04 .2018 & $\begin{array}{l}\text { http:// www.sued d e utsche. } \\
\text { praesidentenwahl-tuerkischer-a } \\
\text { solingen-halten-1.3956239 }\end{array}$ \\
\hline & $\begin{array}{|ll|}\begin{array}{l}\text { Erdoğan hat einen Gegner } \\
\text { weniger }\end{array} \\
\end{array}$ & 28.04 .2018 & $\begin{array}{l}\text { len-in-der-tuerkei- } \\
9\end{array}$ \\
\hline & $\begin{array}{l}\text { AKP stellt Erdogan als Kandidaten } \\
\text { für Präsidentenwahl auf }\end{array}$ & 03.05 .2018 & $\begin{array}{l}\text { http://www.sueddeutsche.de/news/politik/wahlen-akp-stellt- } \\
\text { erdogan-als-kandidaten-fuer-praesidentenwahl-auf-dpa.urn- } \\
\text { newsml-dpa-com-20090.101.180503-99-154743 }\end{array}$ \\
\hline 10 & \begin{tabular}{|l|l|}
$\begin{array}{l}\text { Der Mann, der Erdoğan schlagen } \\
\text { soll }\end{array}$ \\
\end{tabular} & 04.05 .2018 & $\begin{array}{l}\text { ei-der-mann-der- } \\
\text { le }\end{array}$ \\
\hline 11 & $\begin{array}{l}\text { Kämpferischer CHP-Kandidat } \\
\text { tritt gegen Erdogan an }\end{array}$ & 04.05 .2018 & $\begin{array}{l}\text { https://www.sueddeutsche.de/news/politik/wahlen- } \\
\text { kaempferischer-chp-kandidat-tritt-gegen-erdogan-an-dpa.urn- } \\
\text { newsml-dpa-com-20090.101.180504-99-170052 }\end{array}$ \\
\hline 12 & Ein Land als Gerichtssaal & 14.06 .2018 & $\begin{array}{l}\text { http://www-sueddeutsche.de/politik/wahlkampf-in-der-tuerkei- } \\
\text { ein-land-als-gerichtssaal-1.4014851 }\end{array}$ \\
\hline 13 & $\begin{array}{l}\text { Erdogans Herausforderer zieht } \\
\text { Millionenpublikum in Izmir an }\end{array}$ & 22.06 .2018 & $\begin{array}{l}\text { https://www.sueddeutsche.de/news/politik/wahlen-erdogans- } \\
\text { herausforderer-zieht-millionenpublikum-in-izmir-an-dpa.urn- } \\
\text { newsml-dpa-com-20090.101.180622-99-832611 }\end{array}$ \\
\hline 14 & $\begin{array}{l}\text { Was das neue Präsidialsystem für } \\
\text { Veränderungen bringt }\end{array}$ & 22.06 .2018 & $\begin{array}{l}\text { http://www.sueddeutsche.de/politik/wahlen-in-der-tuerkei- } \\
\text { was-das-neue-praesidialsystem-fuer-veraenderungen- } \\
\text { bringt-1.4023748 }\end{array}$ \\
\hline
\end{tabular}

\section{Kaynakça}

Aksoy, S. Z. (2009). The prospect of Turkey's EU membership as represented in the British newspapers the Times and the Guardian 2002-2005. Journal of European Studies 39(4), 469-506.

$\begin{array}{cccccccc}\text { Beschluss (GASP) } & \text { 2017/1426 DES } & \text { RATES } & \text { vom } 4 . \quad \text { August } 2017 . \quad \text { (t.y.). European } \\ \text { Commission. } & 30.08 .2017 & \text { tarihinde } & \text { https://eurlex.europa.eu/legalcontent/DE/TXT/ }\end{array}$


HTML/?uri=CELEX:32017D1426\&from=de\#ntr1L_2017204DE.01009501-E0001 adresinden edinilmiştir.

Bezci, B. (2017). Avrupa'da göç politikaları, İslamofobi ve aşırı ağın yükselişi. B. Bezci, S. Tauscher ve F. Topal (Haz.), Avrupa'da göç ve İslamofobi içinde (s. 1-19). Sakarya: Sakarya Üniversitesi Yayınları.

Blatter, J., Langer, C. P. ve Wagemann, C. (2018). Qualitative methoden in der politikwissenschaft. Wiesbaden: Springer VS.

Cohen, B. C. (1963). The press and foreign policy. New Jersey: Princeton University Press.

Entman, R. M. (1989). Democracy without citizens. New York: Oxford University Press.

Entman, R. M. (1993). Framing Toward Clarification of a Fractured Paradigm. Journal of Communication, 43(5), 51-58.

Damals... Wie alles began. (t.y.). Tageszeitung, 16.07.2018 tarihinde http://www.taz.de/1977--1986/!109039/ adresinden edinilmiştir.

De Vreese C. H. ve Boomgaarden H. G. (2006). Media effects on public opinion about the enlargement of the European Union. Journal of Common Market Studies, 44(2), 419-436.

Die gesamte SZ im Netz. (t.y.). Süddeutsche Zeitung, 17.07.2018 tarihinde https://sz-media.sueddeutsche.de/de/ digital/szde-profil.html adresinden edinilmiştir.

Die taz wird Genossenschaft. (t.y.). Tageszeitung, 16.07.2018 tarihinde http://www.taz.de/1987--1996/!110631/ adresinden edinilmiştir.

Entman, R. M. (1989). Democracy without citizens. New York: Oxford University Press.

Fairclough, N. (1992). Discourse and social change. Cambridge, Polity Press.

Fairclough, N. (1995). Critical discourse analysis: The critical study of language. London: Longman.

Fairclough, N. ve Wodak R. (1997). Critical discourse analysis. Teun van Dijk (Ed.), Discourse as social interaction içinde (s. 258-284). London: SAGE.

Foucault, M. (1981). Archäologie des wissens. Baden Baden: Suhrkamp Verlag.

Geschichte des Süddeutschen Verlages. (t.y.). Süddeutsche Zeitung, 17.07.2018 tarihinde http://www. sueddeutscher-verlag.de/info/facts/geschichte adresinden edinilmiştir.

Giddens, A. ve Sutton, W. P. (2013). Sosyoloji. Mesut Şenol (Çev.) İstanbul: Kırmızı Yayınları.

Habermas, J., (2014). Kamusallı̆̆ın yapısal dönüşümü. T. Bora, Mithat Sancar (Çev.) İstanbul: İletişim Yayınları.

Heiser, P. (2018), Meilensteine der qualitativen Sozialforschung, Eine Einführung entlang klassischer Studien. Wiesbaden: Springer.

Jäckle, S. (Ed.). (2017). Neue Trends in den sozialwissenschaften innovative techniken für qualitative und quantitative forschung. Wiesbaden: Springer.

Jäger, S. (2006). Diskurs und wissen. theoretische und methodische aspekte einer kritischen diskurs und dispositivanalyse. R. Keller, A. Hirseland, W. Schneider ve Viehöver W. (Ed.) Handbuch Sozialwissenchafliche Diskuranalyse. Band 1: Theorien und Methoden içinde (s. 81-112). Wiesbaden: VS Verlag für Sozialwissenchaften.

Kim S. H., Scheufeie D. A. ve Shanahan J. (2002). Think about it this way: Attribute agenda-setting function of the press and the public's evaluation of a local issue. Journalism \& Mass Communication Quarterly, 79(1), 7-25.

Koening, T., Mihelj, S., Downey, J. ve Gencel Bek, M. (2006). Media framing of the issue of Turkish accession to the EU: A European or national process? Innovations, 19(3), 149-169.

Lune, H. ve Berg. B. L. (2017). Qualitative research methods for social sciences. Essex: Pearson Education Limited. 
Madeker, E. (2008). Türkei und europäische Identität, Eine wissenssoziologische Analyse der Debatte um den EUBeitritt. Wiesbaden: VS Verlag für Sozialwissenschaften.

Maigret, E. (2014). Medya ve iletişim sosyolojisi. İ̀stanbul: İletişim Yayınları.

McCombs, N. ve Shaw D. L. (1976). The agenda-setting function of mass media. The Public Opinion Quarterly, 36(2), 176-187.

Negrine, R., Kejanlioglu, B., Aissaoui, R. ve Papathanassopoulos, S. (2008). Turkey and the European Union: An analysis of how the press in four countries covered Turkey's bid for accession in 2004. European Journal of Communication, 23(1), 47-68.

Schneeberger, A. I. (2009). Constructing European identity through mediated difference: A content analysis of Turkey's EU accession process in the British press. Journal of Media and Communication, 1(1), 83-102.

Tauscher, S. (2017), Almanyảda aşırı sağ hareketler ve medyanın suçlu göçmen söyleminin resmi belgeler ışığında incelenmesi. Göç Dergisi, 4(2), 201-226.

Tekin, B. Ç. (2008). The construction of Turkey's possible EU membership in French political discourse. Discourse and Society, 19(2), 727-763.

Tekin, B. Ç. (2010). Representations and other in discourses: The construction of Turkey in the EU context. Philadelphia: John Benjamins.

Unternehmensleitbild. (t.y.). Süddeutsche Zeitung, 17.07.2018 tairihinde http://www.sueddeutscher-verlag.de/ info/facts/portrait adresinden edinilmiştir.

van Dijk, T. A. (1989). Mediating racism: The role of the media in the reproduction of racism. Ruth Wodak (Ed.), Language, power and ideology içinde (s. 199-226). Amsterdam: John Benjamins.

Walter, J. ve Albert M. (2009). Turkey on the European doorstep: British and German debates about Turkey in the European communities. Journal of International Relations and Development, 12(3), 223-250.

Wir über uns. (t.y.). Tageszeitung. 16.07.2018 tarihinde http://www.taz.de/!106557/ adresinden edinilmiştir.

Yardım, M. (2017). Aşırı sağ ve çokkültürlük: Avrupa’da ötekileştirilen "göçmenler”, Akademik İncelemeler Dergisi, 1(2), 217-234.

Zaller, J. (1992). The nature and origins of mass media. New York: Cambridge University Press. 


\title{
A Critical Discourse Analysis of German Media: 24 June 2018 General Elections of Turkey
}

\author{
Soner TAUSCHER ${ }^{*}$ \\ Osman ERDOĞDU ${ }^{* *}$ \\ Şebnem KORKMAZ ${ }^{* * *}$
}

In his book The Press and Foreign Policy, Bernard Cohen (Cohen, 1963) pointed out how the press can affect how people think and therefore affect the foreign policy of the state. In accordance with what Cohen pointed, Maxwell McCombs and Donald Shaw (McCombs and Shaw, 1972, s.176; Maigret, 2014) created Agenda Setting Theory. They stated that the press can set the agenda by simply hiding certain news and constantly giving voice to the ones that suits them. Media can influence the policy making process by simply repeating certain news with a same discourse (Zaller, 1992; Kim et al., 2006; Van Dijk, 1989). Claes De Vreese and Hajo Boomgarden's study on the media's' handling of European Union's enlargement issue shows that medias handling had effect on citizens opinion on the issue (De Vreese\&Boomgarden, 2006). Furthermore, in his book Democracy without Citizens Robert Entman further pointed while journalists and other media workers add their opinions to the news they cover, people also tend to follow media outlets that are in accord with their political ideology, thus enhancing the agenda setting power of the media further (Entman, 1989, s. 31). On the other hand, Jürgen Habermas claimed media's agenda is not only created by political concerns, but also on economic concerns, so in accord with what Entman said media can create an agenda to appeal large political groups even for the sole purpose of economic benefits (Habermas, 2004). Anthony Giddens and Philip Sutton created a four type reader and media relationship model based on the reader attitude (Giddens and Sutton, 2013).

Starting from 2002 events like Arab Spring, Refugee Crisis, and AK Party's 16 years unbroken success and rise of Turkish President Recep Tayyip Erdoğan as a leading political figure in the

\footnotetext{
* $\quad$ Research Assistant, Sakarya Üniversitesi, Diaspora Araştırmaları Merkezi, Sakarya, Türkiye, sonert@sakarya.edu.tr. Orcid ID: 0000-0001-7310-5661

** PhD Candidate, Sakarya Üniversitesi, Diaspora Araştırmaları Merkezi, Sakarya, Türkiye, osman.erdogdu@ogr.sakarya. edu.tr. Orcid ID: 0000-0003-3601-3703

*** Graduate student, Sakarya Üniversitesi, Diaspora Araştırmaları Merkezi, Sakarya, Türkiye, sebnem-korkmaz@outlook. com. Orcid ID: 0000-0003-4830-3118
} 
region have made Turkey the most important country in the region for the Europe and brought the attention of the European media on Turkey. Furthermore, the economic and political turmoil and the rising far-right in Europe also emphasized Turkey's EU ascension process and the refugee crisis (Yardım, 2017; Tauscher, 2017; Bezci, 2017). For these reasons there have been many research about the discourse created on Turkey's relations with Europe (Koening et al., 2006; Madeker, 2008; Negrine et al., 2008; Schneeberg, 2009; Aksoy, 2009; Walter and Albert, 2009).This article will take the German daily newspapers Tageszeitung and Süddeutsche Zeitung to analyze their coverage of latest elections in Turkey and to show the discourse on Turkey and leading political figures and issues in Turkey. Those two newspapers were chosen to see the discourse of the German left on Turkey as they represent the liberal and the radical wings of the left.

Although appearing recently, Critical Discourse Analysis has become one of the most effective methodologies which can examine the relations between the discourse and identity creation (Fairclough and Wodak, 1997; Fairclough, 1992; Fairclough, 1995), such as the creation of the friend and enemy dichotomy which constitutes the heart of national identity creation (Blatter et al., 2018, s. 123). Furthermore, by examining the discourse created in the news, the critical discourse analysis can study the relations between power, language and discourse which were underlined by Michel Foucault (Foucault, 1981). For this ability, critical discourse analysis found use in many disciplines for itself. There are several approaches to the critical discourse analysis (Heiser, 2018; Lune and Berg, 2017; Jäckle, 2017), here this article will use Siegfried Jäger's six-point approach in its analysis (Jäger, 2006). First, the news related to the Turkish elections between 18 April and 24 June were scanned according to a set of keywords. News that contained keywords were evaluated and sorted according to the discourse pattern and the news archive was picked. Conclusions over how each newspaper was covering Turkey's political actors and Turkish democracy were made by analyzing how each newspaper covered the 24 June Turkish elections according to their own respective discourse chains via the patterns and similarities in their own and with other newspaper. From the initial 84 news on the issue, 50 news were chosen for the analysis. After a careful examination discourses created by both newspaper were given separately and in comparison with a separate analysis of the images used on the news.

Each newspapers discourse analysis was made on the discourses created through their news and the images they used in their news. There it was seen that both newspapers shared some similar discourses, but the details of their discourses were different from each other. While both newspapers focused on the announcement of early elections, Süddeutsche Zeitung focuses on state of emergency whereas Tageszeitung linked the early elections with the economic crisis. Another similarity was on the images they used, both newspapers used images where Erdogan is authoritative and alone to support the negative discourse on him. Yet, again the opposition images were different from each other. While Tageszeitung depicted the HDP as people's choice, Süddeutsche Zeitung gave that spot to the CHP. On the other hand, the CHP which was covered as social democrat by the Süddeutsche Zeitung was depicted with religious hints in the Tageszeitung over and over again. However, after this initial similarity their discourses totally changes. The Süddeutsche Zeitung focuses on the how and why Turkish electoral campaign shall be banned in Germany and totally neglects the HDP in 
its news while focusing on the CHP and the AK Party. Tageszeitung on the other hand focuses on economy and the HDP while creating a discourse depicting the election as a total struggle between the HDP and the AK Party. From the language they use to cover the election, it is clear that while the Süddeutsche Zeitung wrote for German policy makers, the Tageszeitung wrote for the commoners. Through the critical discourse analysis of the discourses of the both newspapers, it was found that German media institutions were not reluctant to go beyond their ideological stances or even contradict themselves to create that discourse. The Tageszeitung simultaneously criticizes the AK Party for acting out of the EU defined freedom of speech and political rights, while at the same time it avoids to name the PKK, a terrorist organisation which is also categorized by the EU as terrorist a terrorist organisation. In a similar fashion, the Süddeutsche Zeitung never bases its request for a ban on Turkish political campaign on the German laws, while at the same time criticises the state of emergency as undemocratic and against political freedom. 